\title{
Assessing the Conditions of Rural Road Networks in South Africa using Visual Observations and Field-Based Manual Measurements: A Case Study of Four Rural Communities in KwaZulu-Natal Province
}

\author{
S'phumelele Lucky Nkomo a*, Sumaiya, Desai b, Kabir, Peerbhay c \\ a Researcher, Discipline of Geography, University of KwaZulu-Natal, Pietermaritzburg, South Africa. \\ b Lecturer, Discipline of Geography, University of KwaZulu-Natal, Pietermaritzburg, South Africa. \\ ${ }^{\mathrm{C}}$ Research Scientist, Institute for Commercial Forestry Research, Pietermaritzburg, South Africa \\ *Corresponding author's email address: sphumelelesn@gmail.com .
}

\section{A R T I C L E I N F O}

Received: 29-01-2016

Accepted: 21-02-2016

Available online: 07-03-2016

Keywords:

Rural road conditions, Socioeconomic impacts, Poverty, Road authorities, Rural access.

JEL Classification:

\section{A B S T R A C T}

The prioritization and improvement of rural road networks is important in developing countries in order to uplift the socioeconomic conditions experienced by communities. So far, limited information exists on the conditions of unpaved or gravels roads, particularly in rural areas and the associated implications to rural economies. The present study therefore used visual observations and field-based measurements to assess the physical, environmental and anthropogenic factors affecting Minor roads (R3), Collector roads (R4) and Local roads (R5) in four rural communities in the KwaZulu-Natal Province, South Africa. The function of these road classes is to provide access from homesteads to main roads that connect rural areas to towns. In this study, two classification methods were used to rate the severity and extent of each surface distress on each road class. Results indicate that there was more than one surface distresses identified and assessed on each road class within the selected communities. It was noted that all the road classes had moderate to severe surface distress, except for the R3 road class in Emazabekweni community, reflecting problems associated with poor drainage systems and maintenance. Visual observation and field-based methods are useful tools that can aid in identifying and assessing the physical conditions of unpaved roads, as well as possible environmental, physical and anthropogenic factors at interplay, especially in resource limited regions. This study recommended that road authorities should ensure that proper drainage systems should be well designed; constructed and maintained on all gravel roads in order to reduce surface deterioration associated with runoff.

(C) 2016 The Authors. This is an open access article under the terms of the Creative Commons Attribution License 4.0, which allows use, distribution and reproduction in any medium, provided the original work is properly cited.

DOI: http://dx.doi.org/10.18533/rss.v1i2.24.

\subsection{Introduction}

The prioritization and improvement of rural infrastructure is important in developing countries in order to uplift the socioeconomic conditions experienced by communities (Songco, 2002, Briceno-garmendia \& Estache, 2004; and Bhattacharya et al. 2015). Research done on the importance of rural roads on the economic growth and rural prosperity of communities suggest that improving and expanding rural roads directly increases economic opportunities (Van de walle, 2002, Faiz, 2012 and Porter 2014). In addition, good investment in rural roads yield substantial socioeconomic benefits in terms of improved regional growth, as they allow for the 
movement of agricultural and non-agricultural goods and services between producers and markets in and out the communities (Connerley and Schroeder, 1996; Hanmer et al., 2000; Mwabu and Thorbecke, 2004; Hettige, 2006). For example, a review paper by Faiz, (2012) indicates that in the last decade the improvement and expansion of rural roads in China has had a major impact on their agricultural productivity. In addition, the review stated that well-maintained rural roads enable people to have better access to social services such as health and education facilities, including the movement of labour between residence and the workplace. According to Chambers (2014), the benefit of improved rural road networks has resulted in an increase in urban-rural migration in developed countries, since people make decisions to migrate based on proper infrastructure and access to potential socioeconomic opportunities. In support, Kilkenny (1998) argues that improving rural access attracts new development opportunities, thus decreasing the socioeconomic cost of rural life. However, the controversy is that most studies have assessed the positive impacts of improving rural roads from unpaved to paved roads surfaces.

Research by Alzubaidi and Magnusson (2002) and Zhang and Elaksher (2012) suggest that there have been limited studies undertaken on the impact of unpaved rural roads on the livelihoods of rural people. Moreover there has been a massive slump in research done on gravel roads in developed countries such as Sweden, Norway and Switzerland, when compared to the studies which were done in the 1930s to the 1940s (Alzubaidi and Magnusson 2002). Similarly, research done in South Africa mainly reviews the possible socioeconomic benefits associated with improving the conditions of paved roads. However, limited studies exists which document the conditions of unpaved or gravels roads, particularly in rural areas and the associated implications to rural economies (Bond, 1999). For instance, literature shows that in the Eastern Cape Province, people from these rural areas travel at least ten kilometers to reach the main roads that link them to the major towns (Porter et al. 2010). The study by Nkomo (2014) has revealed that poor rural infrastructure such as road networks makes it difficult for accessing rural areas in most parts of South Africa. This finding is in line with the works of Chamberlin and Jayne, (2012) who indicate that poor road networks in rural areas usually binds these communities into perpetual poverty. It is therefore clear, that the presence of well-developed rural road networks enables communities to develop and sustain their livelihoods (socially and economically). Statistics suggest that about $10 \%$ of the rural population has migrated to urban areas from 1990 to 2011 in South Africa (Potts, 2013). Findings by Chambers and Conway (1992), Tacoli (2003) and Miheretu (2011), argue that there are a number of reasons why rural people migrate to urban areas, but fundamental to them is the issue of poor infrastructure service. Globally, research indicates that despite the advancement in technology, it is yet not possible to obtain an accurate method used to assess the conditions of rural roads (Faiz, 2012). Moreover, the available studies have either focused on roads or rural economies separately, and this does not provide a clear picture on the link between the state of rural roads and associated economic implications. This therefore requires further insight. Also, literature states that countries continue to use rudimentary methods to assess the conditions of their rural roads (Faiz, 2012). The present study therefore seeks to use visual observation and field-based measurements in order to assess the conditions of gravel road networks in selected rural communities in the KwaZulu-Natal Province of South Africa. The overall purpose of the study is to assess the physical conditions of the gravel road networks in rural communities with the purpose to understand the physical, environmental and anthropogenic factors that influence the state of rural roads.

\subsection{Overview of rural roads in South Africa}

Research suggests that only $34 \%$ of the rural people live within $2 \mathrm{~km}$ of all-season roads in Africa, when compared to 65\% in other developing countries (Roberts and Rastogi, 2006, Chamorro and Tighe, 2009). Hence, Figure 1 shows the percentage of Rural Accessibility Index (RAI) in selected African countries. The RAI is an important transport headline indicator which estimates the proportion of rural people with access to adequate transport systems (Roberts and Rastogi, 2006). 
Figure 1: List showing the percentage of Rural Accessibility Index in selected African countries (Sethi ${ }_{2}$ 2008).

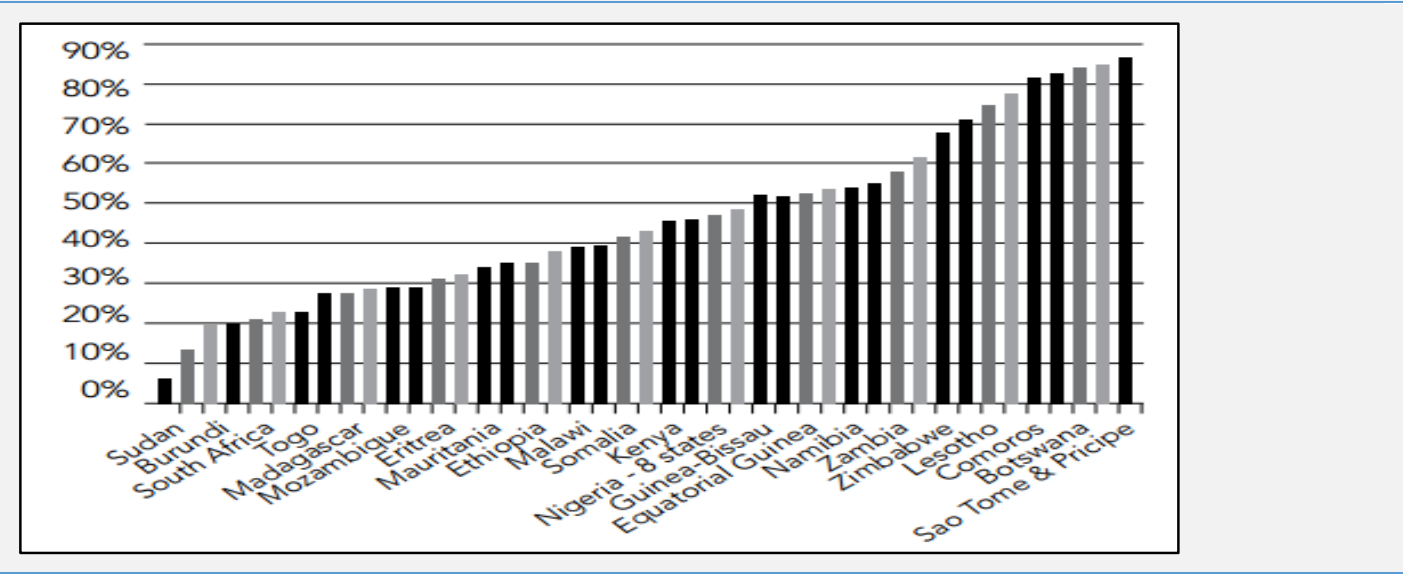

It can be noted from Figure 1 that more than half of the selected countries fall below the 50\% margin for the RAI, of which rural communities in Sudan, Burundi and South Africa are the least accessible. Although the RAI findings do not provide an indication of the conditions of rural roads and demographics characteristics of each country, they provide a comparative overview of rural accessibility in selected African countries. The above findings become extremely important in understanding socioeconomic conditions of rural communities since studies indicate that more than half of the population in Africa still resides in rural areas (Sahn and Stifel, 2003, Cohen, 2006 and Beegle et al. 2016).

Approximately 80\% of rural road networks in South Africa are gravel roads (Gwilliam et al., 2008). Smith and Visser (2001) and Lishman (2013), state that rural networks consist of $301000 \mathrm{~km}$ (gravel) and $63000 \mathrm{~km}$ (surfaced) roads in South Africa. Although, rural and urban roads differ in terms of their scale and standards, they have the same functional purpose (Committee of Transport Officials, 2012). Rural roads are known to have lengthier spreads of connectivity than urban roads (Committee of Transport Officials, 2012). Hence, rural roads in South Africa are classified into two categories and these are based on their main function (Committee of Transport Officials, 2012). Firstly, rural mobility roads connect areas that are large traffic generators (such as cities, towns, villages). Secondly, rural access or activity roads provide access to individual properties, which include farms, settlements and other outline areas. Table 1 provides an overview of the criteria used to differentiate between the classes of rural roads in South Africa (Committee of Transport Officials, 2012). Even though the road functional characteristics provided below are applicable for South Africa's roads, this classification system is used worldwide.

According to Lay (2009), geometric design standards adopted by the South African road authorities, were derived largely from American practices. Although authorities still follow the same American principles, road design and construction practices became localized in order to address South African conditions. The Department of Transport (DoT) is the main government institution that oversees the regulation and delivery of transport services in South Africa (Wenzel, 2007). The National Land Transport Act of 2009 is the main piece of legislation that governs all policy and planning matters related to roads in South Africa. The DoT has established a number of key public entities [including the South African National Roads Agency (SANRAL)] to help deliver on some of the core government's operational activities. All public entities are responsible for different sectors within DoT. For instance, SANRAL manages only activities related to national roads (Mashiri et al. 2002). Other roads are managed by the lower spheres of government and these include; provincial and municipal offices. Rural road networks of interest in this study fall within the roads which are managed at municipal offices.

The recent 2013/2014 financial year report indicates that provinces and municipalities offices received a sum of R18 billion for road construction and maintenance, accounting for $40 \%$ of the R42.3 billion allocated to the DoT (Statistics South Africa, 2014). Moreover, the DoT is estimated to have received a 6\% increase for the 2015 financial year. Although a substantial amount from the total budget is allocated for provincial and municipal offices, there is limited research that exists on the conditions of rural roads networks in South Africa. Literature which is available only looks at how improving rural road network would produce positive spinoffs for rural livelihoods, without referring to the road network conditions. 
Table 1: Description of the different rural road classes and as well as their functional characteristics (Committee of Transport Officials, 2012).

\begin{tabular}{|c|c|c|c|c|c|c|}
\hline $\begin{array}{l}\text { Rural } \\
\text { road } \\
\text { Class } \\
\text { numb } \\
\text { er }(\mathrm{R})\end{array}$ & $\begin{array}{l}\text { Class } \\
\text { name }\end{array}$ & Origin/destination & $\begin{array}{l}\text { Through } \\
\text { traffic } \\
\text { component }\end{array}$ & $\begin{array}{r}\text { Reach of } \\
\text { connectivity }\end{array}$ & $\begin{array}{r}\% \text { of } \\
\text { built km }\end{array}$ & $\begin{array}{r}\text { AADT } \\
\text { (average } \\
\text { annual daily } \\
\text { traffic }\end{array}$ \\
\hline R1 & $\begin{array}{l}\text { Principal } \\
\text { arterials }\end{array}$ & $\begin{array}{l}\text { Metro areas, large cities, large border } \\
\text { posts, join national routes }\end{array}$ & Exclusively & $>50 \mathrm{~km}$ & & $\begin{array}{r}1000-100 \\
000+\end{array}$ \\
\hline R2 & $\begin{array}{l}\text { Major } \\
\text { arterials }\end{array}$ & $\begin{array}{l}\text { Cities and large towns, transport } \\
\text { nodes (harbours and international } \\
\text { airports), smaller border posts, join } \\
\text { major routes }\end{array}$ & Exclusively & $>25 \mathrm{~km}$ & $\begin{array}{l}2-4 \% \\
\text { Classes } \\
1 \text { and } 2\end{array}$ & $\begin{array}{r}500-25 \\
000+\end{array}$ \\
\hline R3 & $\begin{array}{l}\text { Minor } \\
\text { road }\end{array}$ & $\begin{array}{l}\text { Towns, villages and rural settlements, } \\
\text { tourist destinations, transport nodes } \\
\text { (railway sidings, seaports, landing } \\
\text { strips), small border posts, other } \\
\text { routes }\end{array}$ & Predominant & $>10 \mathrm{~km}$ & $\begin{array}{r}6-12 \% \\
\text { Classes } \\
1,2 \text { and } \\
3\end{array}$ & $100-2000+$ \\
\hline R4 & $\begin{array}{l}\text { Collector } \\
\text { road }\end{array}$ & $\begin{array}{l}\text { Connect farming districts, rural } \\
\text { settlements, tourist areas, national } \\
\text { and private parks and mines to } \\
\text { mobility routes }\end{array}$ & Minimal & $<10 \mathrm{~km}$ & $\begin{array}{r}20- \\
25 \%\end{array}$ & $<1000$ \\
\hline R5 & $\begin{array}{l}\text { Local } \\
\text { road }\end{array}$ & $\begin{array}{l}\text { Farm or property access, connection } \\
\text { to other routes }\end{array}$ & $\begin{array}{l}\text { Nil } \\
\text { Discontinuous }\end{array}$ & $<5 \mathrm{~km}$ & $\begin{array}{r}65- \\
75 \%\end{array}$ & $<500$ \\
\hline R6 & $\begin{array}{l}\text { Walkway } \\
\text { (path or } \\
\text { track) }\end{array}$ & $\begin{array}{l}\text { Settlements, farms, transport nodes, } \\
\text { water points }\end{array}$ & $\mathrm{n} / \mathrm{a}$ & $\mathrm{n} / \mathrm{a}$ & $\mathrm{n} / \mathrm{a}$ & $\mathrm{n} / \mathrm{a}$ \\
\hline
\end{tabular}

\subsection{Challenges associated with physical conditions of rural road networks}

Problems associated with physical conditions of rural roads differ from one area to another. According to Forman (2003), it is important to understand the different types of rural road surfaces before one can assess the associated problems. Firstly, paved roads generally consist of asphalt or concrete surfaces, which is very rare for rural communities in developing countries. Secondly, unpaved road surfaces in most rural communities consist of gravel or dirt roads. Hence, the present study only assesses conditions associated with unpaved rural road surfaces. The most common challenge associated with unpaved roads is the deterioration of the road surface. Factors such as the behavior of road material, the drainage capacity and maintenance activities, determine the rate and level of deterioration of gravel roads. Hence, Figure 2 provides a schematic overview of the processes and distresses associated with the deterioration of gravel roads.

Figure 2: Processes which influence the deterioration of gravel roads (Alzubaidi and Magnusson, 2002).

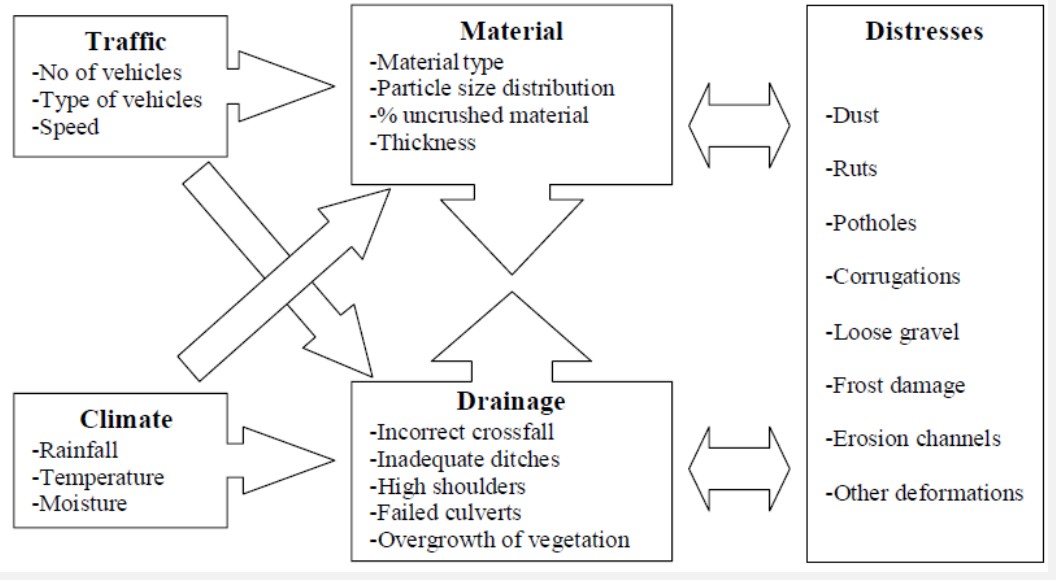


As illustrated in Figure 2, climate and traffic conditions directly impact on the behavior of road material and the drainage capacity of gravel roads. The listed distresses are some of the observable features of surface deterioration on gravel roads. However, deteriorated surfaces can show features of multiple distresses on a single gravel road. Severely deteriorated surfaces affect mobility and ride comfort on gravel roads. A number of studies have assessed and reviewed possible causes of surface deterioration on gravel roads as a result of the behavior of road material and drainage problems; however, associated findings suggest that such problems require site specific analysis and interpretation of causalities (Jones, 1984, Shoop et al. 2008, Fu et al. 2010). Similarly, there are different criteria's (based on the receiving environment) used to assess and rate the conditions of unpaved or gravel roads.

\subsection{Methods of assessing and rating of unpaved or gravel roads}

There is no standardized method used to assess and rate the conditions of unpaved or gravel roads. Alzubaidi (2000), suggests that road conditions have been traditionally assessed using subjective methods. In reviewing literature, a number of studies have criticised the use of subjective methods arguing that they produce only qualitative results (Alzubaidi 2000, Huntington and Ksaibati, 2005, van der Gryp and van Zyl, 2007). van der Gryp and van Zyl (2007), suggest that gravel roads should be objectively assessed in order to eliminate subjective perceptions and also to provide reliable and quantifiable information for future research. Several studies have also attempted to objectively assess and rate surface condition on gravel roads, but found out that they require highly specialized experts, costly equipment and is time consuming (van der Gryp and van Zyl, 2007). Similarly, Maser (1996) argues that the use of objective methods alone in assessing and rating of gravel roads is irrational, because surface conditions change rapidly. Rainfall conditions, traffic volumes and maintenance activities have the ability to modify the characteristics of gravel road surface conditions within a short period of time (Huntington and Ksaibati, 2007).

\subsection{Description of the study areas}

The study was conducted in four rural tribal communities (i.e. Emazabekweni, Dukuza, Mkhunya and Mhlwazini) in the KwaZulu-Natal Province of South Africa. Emazabekweni and Mkhunya are situated in the midlands while Mhlwazini and Dukuza are located in the north-western part of the Province (Figure 3). In South Africa, KZN is the second largest province with a population of approximately 10.5 million people in an area of $94,361 \mathrm{~km}^{2}$ (Housing Development Agency, 2013). The 2013 report on Informal Settlement Status in KZN indicates that $46 \%$ of the population live on traditional/tribal land, while $47 \%$ in urban areas and the remaining $7 \%$ on private farms (Housing Development Agency, 2013). Although the population in KZN is distributed amongst a large area $\left(94,361 \mathrm{~km}^{2}\right)$, the terrain and climatic conditions of the province differ and therefore given below is the brief description of the communities under study.

Emazabekweni and Mkhunya communities are situated under Ubuhlebezwe Local Municipality (ULM), ward 9 and 5, respectively. ULM has a total of 12 wards and approximately 110000 inhabitants, with an annual growth rate of $0.5 \%$ (Ubuhlebezwe Local Municipality, 2015). From the total population of ULM, ward 5 and 9 have approximately $10 \%$ of the inhabitants, 12000 and 9000 respectively (Ubuhlebezwe Local Municipality, 2015). The community of Emazabekweni is located about $2 \mathrm{~km}$ from the R612 regional road and approximately $15 \mathrm{~km}$ from a small town called Highflats. Mkhunya community is approximately $40 \mathrm{~km}$ from R612 regional road and the town of Highflats. The exact location of the communities using the Global Positioning Systems (GPS) is, 30

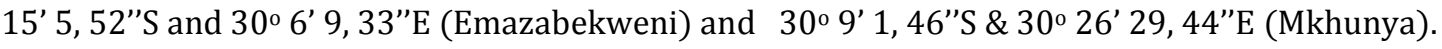

Mhlwazini and Dukuza communities fall within Okhahlamba Local Municipality (OLM), ward 3 and 4 respectively. The OLM has a total of 14 wards and approximately 140000 inhabitants. Results from the Integrated Development Plan (IDP) 2013/2014 indicate that the annual population growth rate for the OLM is at $-0.43 \%$ and this is caused by inhabitants migrating to neighboring municipalities to seek for better living conditions (Okhahlamba Local Municipality, 2015). The IDP further indicates that ward 3 and 4 have approximately 11000 and 10000 inhabitants, respectively. Although both communities are located in one municipality, Mhlwazini is about $40 \mathrm{~km}$ from the town called Winterton and less than $500 \mathrm{~m}$ from the R600 regional route. Dukuza community is approximately $20 \mathrm{~km}$ from a town called Bergville and less than $100 \mathrm{~m}$ from the R74 provincial route. Using the Global Positioning Systems (GPS) the location of the communities is, $28^{\circ} 56^{\prime}$

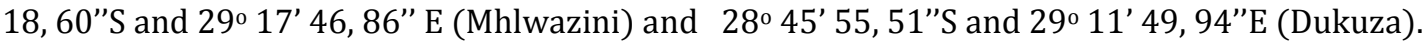


Figure 3: Map showing the location of the four rural areas under study

\subsection{Materials and methods}

\subsection{Identification and classification of rural road networks}

Road networks of interest were identified by first traversing the selected communities using recent high resolution Google Earth images. Following the above procedure, transect walks were done in each community in order to identify and classify the road networks respectively. Road networks were then classified using the South African Road Classification and Access Management Manual, version 1.0 of August 2012 (Table 1). Due to the focus of this study, Principal arterials (R1), Major arterials (R2) and Walkways (R6) road classes were not assessed. This was due to the fact that the study aimed at assessing the conditions of rural roads which provided access from major/ principal arterials [i.e. Minor road (R3), Collector road (R4) and Local road (R5)] to homesteads. In assessing the road conditions, this study did not assess the technical engineering (such as the quality of road material, type of machinery used, expertise of the engineers) components of road construction. However, without ignoring the influence and importance of the technical engineering components, the focus of this study was to assess the physical conditions of rural road networks and their implications on road users. In this study the term 'physical condition' referred to the quality of the road surface (for freedom of vehicle movement) under the influence of human and environmental factors. In assessing the quality of the road surface, this study examined the behavior of road material, the drainage capacity and maintenance activities. The behavior of road material was examined by firstly identifying the apparent surface distresses and thereafter, assessing their severity and extent in each road class. As illustrated in Figure 2, the behavior of road material under the influence of traffic and climatic conditions results in the development of distresses which ultimately deteriorate the quality of the road surface.

Research conducted by Chamorro et al. (2009), suggest that there is no single method used to assess and rate the conditions of distresses on gravel roads. According to Chamorro et al. (2009), most studies have assessed distresses by dividing gravel roads into segments and used visual assessment methods to estimate for the entire road. Studies by Chamorro et al. (2009) and Rivera et al. (2015) have criticised the assessment of distresses through this method, arguing that the results obtained did not provide accurate estimation of the conditions of the entire road surface. However, Chamorro et al. (2009) argues that the accuracy of the results obtained should be determined by the reliability of the methods used and the total road length assessed. The present study used visual observation and field-based manual measurements to assess the physical conditions of the entire road surface in each road class under study.

\subsection{Assessing and rating of the road conditions}

The R3, R4 and R5 road surfaces were traversed in each community with the aim of identifying the type of distresses apparent. Thereafter the extent of their existence was assessed. Distresses such as potholes, rutting, erosion channels, corrugations, loose material and stoniness were assessed to determine the quality of gravel surfaces. Although, surfaces distress were identified for the entire road surface, their severity and extent were only assessed on the parts of the road that impacted on ride comfort in each road class. Hence, a tape measure was used to calculate the depth and width of distresses such as potholes, rutting and erosion channels in order Review of Social Sciences. 
to determine their severity. Table 2, provides the general description used to classify the severity of each distress (Jones, 2000). For the purpose of this study, if the aforementioned distresses had a depth and width less than $15 \mathrm{~cm}$, their severity ratings were classified between $0-4$ and anything more than $15 \mathrm{~cm}$ was given the rating of 5. This method was adopted and modified from Jones (2000) rating systems. However, the severity of surface distresses such as corrugations, loose material and stoniness were assessed and rated based on visual perceptions.

Table 2: Overview of the rating system used to assess the severity of each distress (adopted from Jones, 2000)

\begin{tabular}{lll}
\hline Degree & Severity & Description \\
\hline 0 & None & No distress visible \\
1 & Slight & Distress difficult to discern. Only the first signs of distress are visible. \\
& $\begin{array}{l}\text { Between slight and } \\
\text { warning }\end{array}$ & \\
Warning & $\begin{array}{l}\text { Distress is distinct. Start of secondary defects. (Distress notable with } \\
\text { respect to possible consequences. Maintenance might be required in near } \\
\text { future e.g. potholes can be removed by blading) }\end{array}$ \\
4 & $\begin{array}{l}\text { Between warning } \\
\text { and severe }\end{array}$ & $\begin{array}{l}\text { Distress is extreme. Secondary defects are well-developed (high degree of } \\
\text { secondary defects) and/or extreme severity of primary defect. (Urgent } \\
\text { attention required e.g. potholes require manual repair). }\end{array}$ \\
\hline 5
\end{tabular}

As illustrated in Table 2, all distresses with uncertainties regarding their degree of severity were classified as 1 or 4. The severity of each distress was only assessed on the parts of the road that impacted on ride comfort in each road class (R3, R4 and R5). Thereafter, a handheld Garmin etrex GPS with sub-meter accuracy was used to located the distresses in order to determine the widespread of each distress over the total length of the road. Table 3, provides the classification method used to assess the extent of each distress.

Table 3: Overview of the classification systems used to assess the extent of each distress (adopted from Jones, 2000)

\begin{tabular}{|c|c|c|}
\hline Extent & Description & $\begin{array}{r}\text { Estimate } \\
(\%)\end{array}$ \\
\hline A & $\begin{array}{l}\text { Isolated occurrence, not representative of the segment length being evaluated. They are } \\
\text { usually associated with localized changes in the material, subgrade or drainage conditions. } \\
\text { Intersections, steep grades or sharp curves may also result in isolated occurrences. }\end{array}$ & $<5$ \\
\hline B & & $5-20$ \\
\hline $\mathrm{C}$ & $\begin{array}{l}\text { Intermittent occurrence, over most of the segment length, or extensive occurrence over a } \\
\text { limited portion of the segment length. When occurring over most of the segment length, } \\
\text { problems are usually associated with the material quality or maintenance procedures. When } \\
\text { occurring over limited portions, the problem is usually a result of local material variations or } \\
\text { drainage problems. }\end{array}$ & $20-60$ \\
\hline D & & $60-80$ \\
\hline $\mathrm{E}$ & $\begin{array}{l}\text { Extensive occurrence. This is usually a result of poor quality or insufficient wearing course } \\
\text { material, or inadequate maintenance. }\end{array}$ & $80-100$ \\
\hline
\end{tabular}

Using the above classification, the extent of each distress was recorded only for the width of the road that was affecting traffic. Assessing the distresses on each road class was an indication of the behavior of road material under the influence of traffic and climatic conditions. Furthermore, drainage and maintenance conditions were assessed on each road class in order to determine their influence. Drainage and maintenance conditions were assessed using techniques adopted from the Massachusetts Manual of Investigating Unpaved Roads (Berkshire Regional Planning Commission, 2001). The Massachusetts manual is designed to help local road developers gain a better understanding of the types of problems that occur as a result of improper design, construction and maintenance of drainage on unpaved roads. Roadside drainage consists of three important components namely; ditches, culvers and turnouts (Yifred, 2013). Studies done by Jones (1984) suggest that poorly designed, constructed and maintained roadside drainage systems contribute significantly to the deterioration of surface on gravel roads. The condition of each roadside ditch, if available, was assessed at every 500m intervals in each 
road class and the number of intervals were determined by the total distance of the road traversed. All culverts and turnouts identified were assessed in each road class. Table 4, provides the classification method used to assess and rate drainage and maintenance conditions in each road class.

\begin{tabular}{ccccc}
\hline \multicolumn{5}{c}{ Table 4: Overview of the classification system used to assess and rate the drainage systems on each road } \\
class (adopted from Jones, 2000).
\end{tabular}

\subsection{Data analysis}

The data analysis was done using Statistical package for Social Sciences (SPSS) version 17.1 software. This analysis was performed in order to obtain descriptive statistics, such as frequencies and cross tabulations. Cross tabulation was used to summarize categorical data (surfaces distresses) in order to assess the variations in surface distresses amongst the different road classes. The collected GPS coordinates were imported and displayed in a GIS environment using Arc GIS 10.1. This was done in order to locate the spatial distribution of distresses that impacted on ride comfort in each road class.

\section{$4.0 \quad$ Results}

\subsection{Characteristics of the road networks}

The characteristics of the road networks under study are presented in Table 5. Results show that road characteristics differed for each community. The average gradient for the different road classes ranged between $0-20 \%$ for Emazabekweni and Dukuza communities when compared to Mkhunya and Mhlwazini communities (0-50\%). Similarly, the average hourly traffic for the different road classes ranged higher (from 0-50) for Emazabekweni and Dukuza communities when compared Mkhunya and Mhlwazini communities (0-15). In each community, the R5 roads had a lower average road width when compared to the R3 and R4 roads.

Table 5: Number of households as well as the characteristics of each road class in the different communities Road characteristics

\begin{tabular}{|c|c|c|c|c|c|c|}
\hline Community & $\begin{array}{l}\text { Total number } \\
\text { of households }\end{array}$ & $\begin{array}{r}\text { Class } \\
\text { number (R) }\end{array}$ & $\begin{array}{r}\text { Average road } \\
\text { gradient } \\
(0 \%)\end{array}$ & $\begin{array}{r}\text { Total road } \\
\text { length }(\mathrm{km})\end{array}$ & $\begin{array}{l}\text { Average road } \\
\text { width }(\mathrm{m})\end{array}$ & $\begin{array}{r}\text { Average hourly } \\
\text { traffic }\end{array}$ \\
\hline \multirow{3}{*}{$\begin{array}{l}\text { Emazabekwe } \\
\text { ni }\end{array}$} & 251 & R3 & $0-20$ & 20 & 8 & $20-50$ \\
\hline & & R4 & $0-10$ & 8 & 5 & $5-10$ \\
\hline & & R5 & $0-10$ & 6 & 4 & $0-5$ \\
\hline \multirow[t]{3}{*}{ Dukuza } & 525 & R3 & $0-10$ & 17 & 7 & $15-50$ \\
\hline & & R4 & $0-20$ & 7 & 6 & $5-10$ \\
\hline & & R5 & $0-10$ & $20^{*}$ & 5 & $5-10$ \\
\hline \multirow[t]{3}{*}{ Mhlwazini } & 156 & $\mathrm{R}^{* *}$ & - & - & - & - \\
\hline & & $\mathrm{R} 4^{* *}$ & - & - & - & - \\
\hline & & R5 & $30-50$ & 6 & 5 & $0-5$ \\
\hline \multirow[t]{3}{*}{ Mkhunya } & 353 & R3 & $10-50$ & 38 & 5 & $5-15$ \\
\hline & & $\mathrm{R} 4$ & $10-50$ & $10^{*}$ & 5 & $0-5$ \\
\hline & & R5 & $0-20$ & 2 & 4 & $0-5$ \\
\hline
\end{tabular}




\subsection{Road surface conditions}

Table 5 presents a list of identified and assessed distresses in each road class. Numbers 0 to 5 are used to rate the severity of each distresses and A to E determine the extent of each distress on a particular road class (as see on Table 3 and 4). It can be noted from Table 6 that in each road class, there were more than one distresses identified. However, the extent of each distress was only measured for the distresses that affected drive comfort (i.e. distress with severity rating of 3 to 5). In Emazabekweni and Dukuza communities, the R3 road classes have better surface conditions than the R4 and R5 classes. Moderate to severe distresses (erosion channels and loose material) dominated and deteriorated the surfaces conditions of the R4 and R5 road classes. Whereas in Mkhunya and Mhlwazini communities, all assessed road class (i.e. R3, R4 and R5) had moderate to severe distresses deteriorating the surface conditions. Figure 4 shows the difference in surface conditions on the R3 road classes for Emazabekweni, Dukuza and Mkhunya communities.

\begin{tabular}{|c|c|c|c|c|c|c|c|}
\hline \multicolumn{8}{|c|}{ Table 6: Identified distresses, their severity and extent in each road class } \\
\hline \multicolumn{7}{|c|}{ Apparent distresses } & \multirow[b]{2}{*}{ Stoniness } \\
\hline Communities & $\begin{array}{l}\text { Road } \\
\text { class }\end{array}$ & Potholes & Rutting & $\begin{array}{r}\text { Erosion } \\
\text { channels }\end{array}$ & Corrugations & $\begin{array}{r}\text { Loose } \\
\text { material }\end{array}$ & \\
\hline \multirow{3}{*}{ Emazabekweni } & R3 & 0 & 0 & 0 & 2 & 1 & $3[\mathrm{~A}]$ \\
\hline & R4 & 1 & 0 & $3[\mathrm{C}]$ & 1 & $3[\mathrm{C}]$ & 1 \\
\hline & R5 & $3[\mathrm{~A}]$ & 1 & $5[\mathrm{E}]$ & 1 & 3 [B] & 2 \\
\hline \multirow{3}{*}{ Dukuza } & $\mathrm{R} 3$ & $3[\mathrm{~A}]$ & 1 & 3 [B] & 1 & 0 & 1 \\
\hline & $\mathrm{R} 4$ & $5[\mathrm{D}]$ & 1 & $3[\mathrm{C}]$ & 2 & $3[\mathrm{C}]$ & $3[\mathrm{C}]$ \\
\hline & R5 & 5 [D] & 2 & $3[\mathrm{C}]$ & 0 & $3[\mathrm{C}]$ & $3[\mathrm{C}]$ \\
\hline \multirow[t]{3}{*}{ Mkhunya } & R3 & 1 & $3[\mathrm{C}]$ & $4[\mathrm{D}]$ & 1 & $5[\mathrm{E}]$ & 1 \\
\hline & $\mathrm{R} 4$ & $3[\mathrm{C}]$ & $3[\mathrm{C}]$ & $5[\mathrm{C}]$ & 0 & 2 & $3[\mathrm{C}]$ \\
\hline & $\mathrm{R} 5$ & $3[\mathrm{C}]$ & $3[\mathrm{~B}]$ & $5[\mathrm{C}]$ & 0 & 2 & $3[\mathrm{C}]$ \\
\hline Mhlwazini & R5 & 1 & 0 & $5[\mathrm{E}]$ & 0 & $5[\mathrm{C}]$ & $5[\mathrm{C}]$ \\
\hline
\end{tabular}

Figure 4: View of the surface conditions on the R3 road classes in (A) Emazabekweni, (B) Dukuza and (C) Mkhunya communities
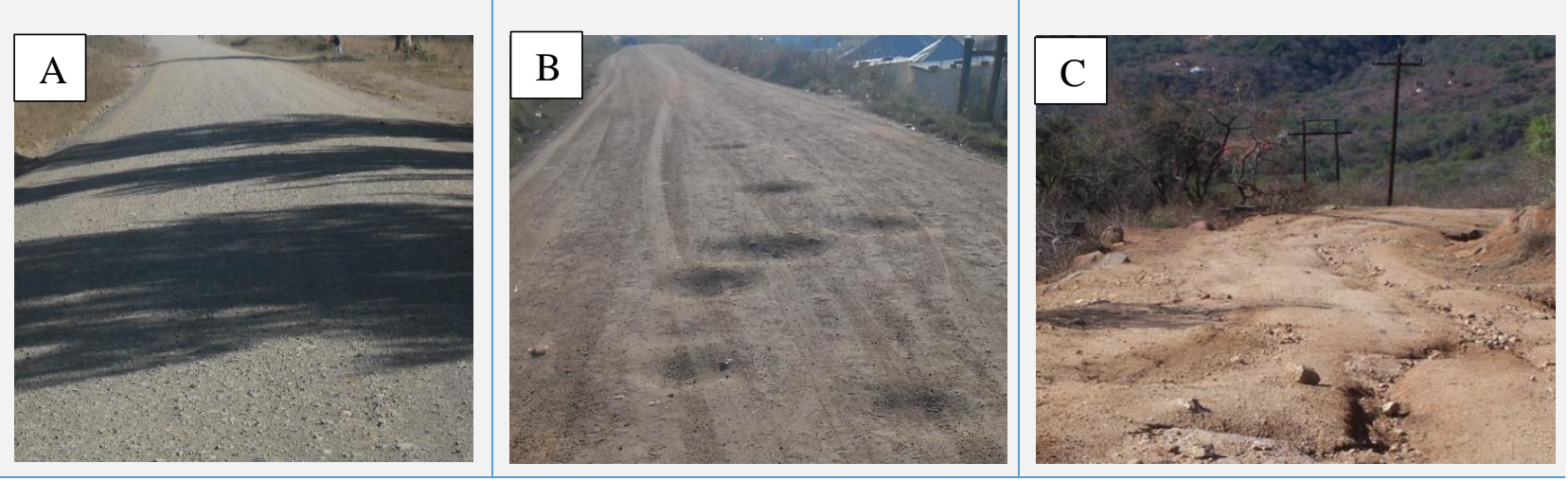

\subsection{Drainage and maintenance conditions}

The results presented on Table 7 illustrate the ratings of drainage conditions for each road class. It can noted that in all the communities, the R4 and R5 road classes had drainage ratings of 1 when compared to the R5 road classes with a drainage rating of 3. Overall, none of the road classes obtained drainage ratings of 5. Hence, Figure 5 shows some of the challenges associated with drainage conditions on the R3 road classes in Emazabekweni, Dukuza and Mkhunya communities.

\begin{tabular}{lrr}
\hline & Table 7: Drainage rating results in each road class & \\
\hline Community & Road class & Drainage ratings \\
\hline Emazabekweni & R3 & 3 \\
& R4 & 1 \\
Dukuza & R5 & 1 \\
& $\mathrm{R} 3$ & 3 \\
& $\mathrm{R} 4$ & 1 \\
& $\mathrm{R} 5$ & 1 \\
\hline
\end{tabular}




\begin{tabular}{lll}
\hline Mkhunya & R3 & 3 \\
& R4 & 1 \\
& R5 & 1 \\
Mhlwazini & R5 & 1 \\
\hline
\end{tabular}

\subsection{Rainfall characteristics}

It can be noted that Mhlwazini community receives more annual rainfall (approximately $1389 \mathrm{~mm}$ ) than the other communities. However on average, all the communities received more than $600 \mathrm{~mm}$ of rainfall every year.

Figure 5: View of poorly maintained drainage systems on the R3 road classes in Emazabekweni (A), Dukuza (B and D) and Mkhunya (C) communities.
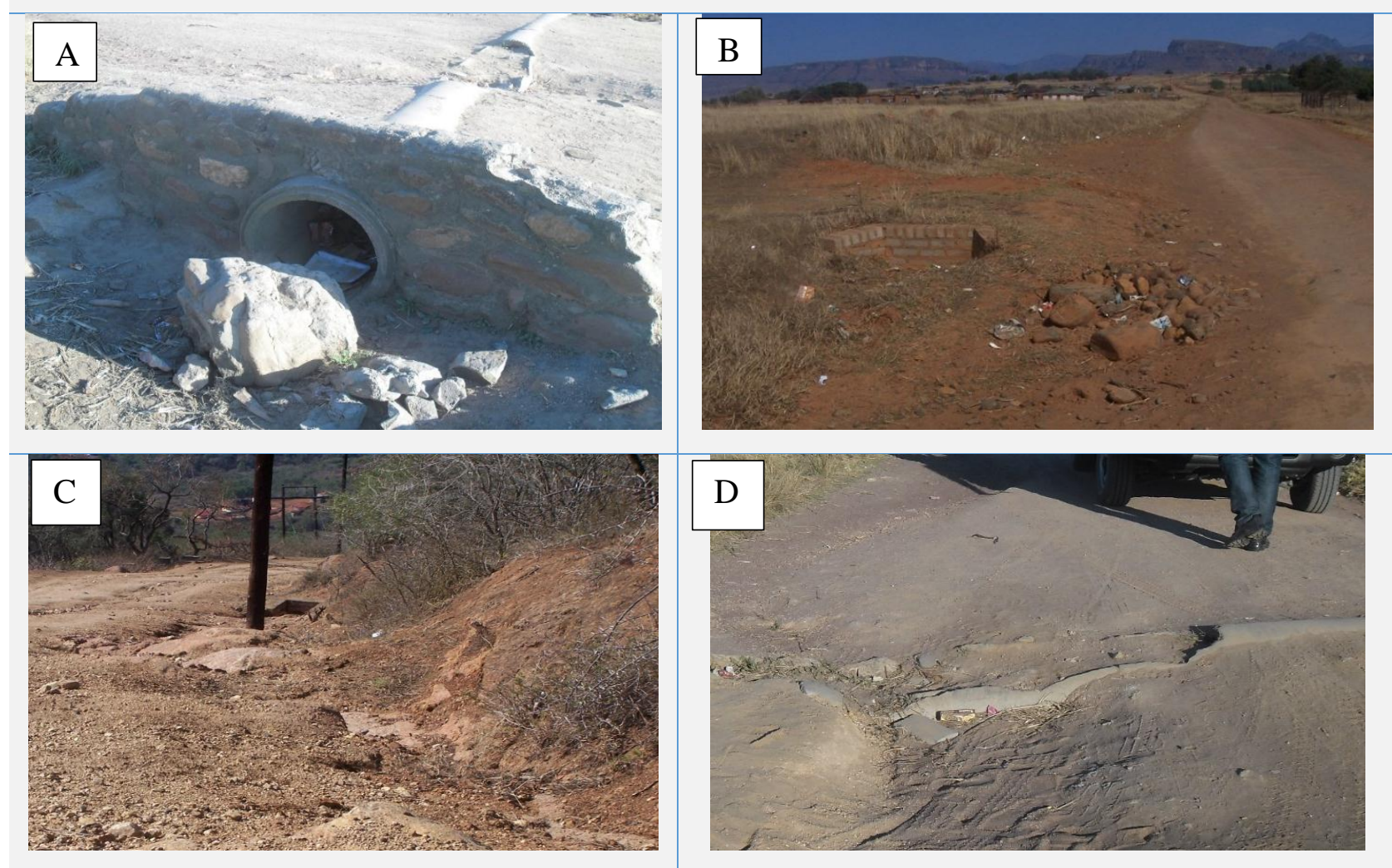

Figure 6: Annual rainfall for the communities under study (Schulze, 2008).

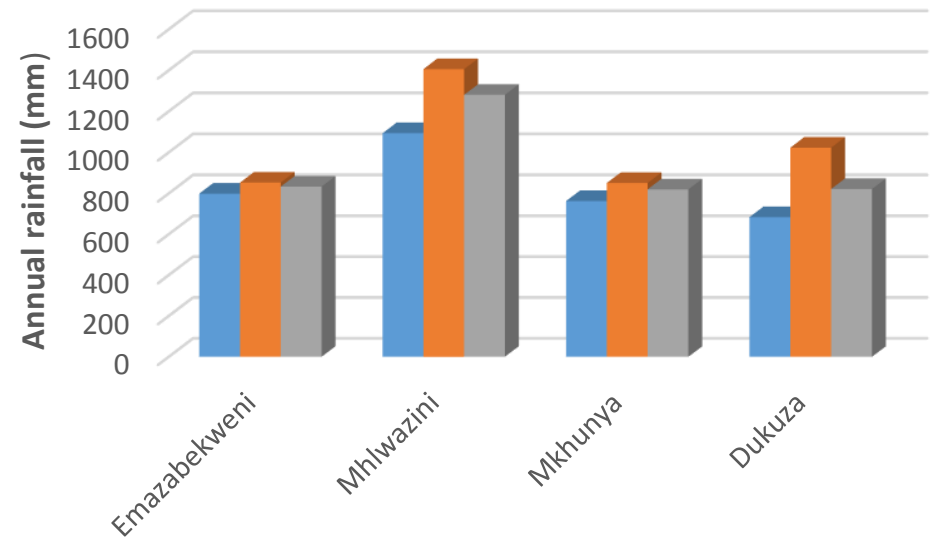

Min

- Max

Mean

Communities 


\subsection{Discussions}

Understanding the physical conditions of unpaved rural roads could serve as a primary platform which could be used to assess the socioeconomic conditions in rural communities. In this study, the physical conditions of selected road classes were determined by assessing the influence of physical, environmental and anthropogenic factors. Research indicates that despite the advancement in technology, it is yet not possible to obtain an accurate method to assess the conditions of rural roads globally. In the present study, visual observation and field-based methods were used to identify, assess and rate the physical conditions of gravel roads.

Overall, the results of this study indicate that there is a direct relationship between road surface characteristics, drainage and maintenance conditions. For instance, it was noted that the road classes with moderate to severe surface distresses had very poor drainage and maintenance conditions when compared to those with slight surface distresses. However, it was further noted that the nature of surface distresses identified were also an indication of the influence of traffic and climate conditions. These results are comparable to previous studies which indicate that surface conditions are determined by the behavior of the road material and drainage capacity under the influence of traffic and climate conditions (Simonsen and Isacsson, 1999, Lugo and Gucinski, 2000 and Alzubaidi and Magnusson, 2002). Moreover, poor surface conditions directly impact on traffic volumes. For example, the results indicate that more average hourly traffic volumes were recorded for the R3 road classes (15-50) in Emazabekweni and Dukuza communities when compared to the R3 road class in Mkhunya community (5-15). The difference in traffic volumes could also be a reflection of the surfaces conditions. This is due to the fact that findings on Table 6 show that the R3 road classes in Emazabekweni and Dukuza communities had less severe surface distresses than in Mkhunya community (as seen on Figure 4). Although the R3 road surface conditions may be different, the most important factor to be noted is that these road classes have the same function in rural communities. The function of the R3 road class is to connect rural settlements to major arterials (such as the R2). This means that these road classes play a primary role in connecting rural settlements with roads leading to large economic hubs. It is therefore important to ensure that the R3 road classes are well designed constructed and maintained. Hetzel et al. (2007) argues that wellmaintained rural roads enable people to have better access to social services and they also allow for the movement of labour between residence and workplace. However, surface conditions on the R4 and R5 road classes are just as important because they provide access to the R3 road class. Research suggests that only $34 \%$ of the rural people live within $2 \mathrm{~km}$ of all-season roads in Africa, compared to $65 \%$ in other developing countries (Chamorro and Tighe, 2009, Roberts and Rastogi, 2006).

The surface conditions in all the R4 and R5 road classes were dominated by moderate to severe surface distresses. Depending on the size of the community, the R4 and R5 road classes are used as primary roads that connect livelihoods to the R3 road classes. Hence, there is a need to ensure that these road classes are well designed, constructed and maintained in order to make rural communities more accessible.

Although the R3 road classes had drainage systems, it was noted that the lack of maintenance affected their function. For instance, all identified roadside ditches, turnouts and culverts were either clogged with sediment, debris or overgrown with vegetation The identified surface distresses (such as erosion channels and potholes) on the R3 road classes reflected ineffective drainage systems, which contributed to road surface deterioration, particularly on the R3 road classes of Dukuza and Mkhunya communities. In all the communities, the R4 and R5 road classes had no roadside drainage systems. The lack of drainage systems resulted in moderate to severe surfaces distresses dominating these road classes. All the communities under study receive average annual rainfall which is above $700 \mathrm{~mm}$. It is therefore important to ensure that all the road classes under study have proper and effective drainage systems because rainfall conditions and traffic volumes have the ability to modify the characteristics of gravel road surface conditions within a short period of time (Huntington and Ksaibati, 2007).

The findings of this study have demonstrated that visual observation and field-based methods are useful tools that can aid in identifying and assessing the physical conditions of unpaved roads as well as possible environmental, physical and anthropogenic factors at interplay, especially in resource limited regions (i.e. where there is limited funds available for advance technology) such as sub-Saharan Africa. Even though the use of more technologically advanced methods will be useful to avoid manual field work for faster and accurate results and also to eliminate different assessor perceptions, the methods used in this study were more appropriate and cost efficient. As argued by Maser (1996), the use of objective methods alone in assessing and rating of gravel roads is irrational because surface conditions change rapidly. Moreover, identifying surfaces distresses using high-tech equipment will be challenging and very expensive, because it will require the use of technologies with high image resolution. In future, there is a need to develop technology that will be attached to a vehicle which will be 
able to detect, distinguish and map the severity and extent of surface distresses and as well as detect factors, such as dust. This system will be faster and more accurate than using traditional methods. However, the findings of this study could be useful to road authorities responsible for unpaved rural roads in sub-Saharan Africa. For instance, the understanding of factors affecting the quality of unpaved roads and the ability to identify and assess surface distresses is key to assisting both road authorities and local people deal with challenges associated with unpaved roads. This study was able use cost effective, user-friendly methods to identify and assess surface distresses on unpaved roads. This implies that road authorities could train local people on how to use this method so that they are able to identify, assess and report or help mitigate surface distresses developing on their local roads. Empowering local people will help improve the quality of unpaved roads and as well as enhance socioeconomic conditions in rural communities.

\subsection{Conclusion}

This study aimed at assessing the physical conditions of selected rural road networks to understand the physical, environmental and anthropogenic factors that influence the condition of rural roads. The results of this study recommend that the characteristics of road classes under study strongly reflected on the effectiveness of drainage and maintenance conditions. For instance, the nature (type, severity and extent) of surface distresses identified on each road class were an indication of the presence and effectiveness of drainage and maintenance conditions. In all the road classes under study, Mkhunya and Mhlwazini communities had more deteriorated road surface conditions than Dukuza and Emazabekweni communities. It was also noted that the more deteriorated the road class, the less traffic movement. Overall, the results indicate that there is a need for road authorities to ensure that rural road networks are well maintained and have proper drainage systems. For instance, the identified and assessed surface distresses indicated that the road networks reflected the need for proper drainage systems and regular maintenance. Therefore, proper drainage systems and regular maintenance is recommended. While this study was able to use user-friendly and cost-effective methods to assess the physical conditions of rural road networks, explicit investigations are required to aid with the quality of observations. Future research should focus on assessing the impact of road designs, landscape characteristics, and the quality of road materials used and associated cost of maintenance. The results of this study can help municipal authorities in carrying out regularly monitoring procedures thus ensuring that surface distresses are identified and resolved during their initial stage. If not, road authorities could train local people on how to use this method so that they are able to identify, assess and report or help mitigate surface distresses developing on their local roads. More importantly, the assessment method used in this study could help local municipal authorities develop a better management system for their rural road networks. For example, using this assessment method, authorities could create their own database indicating the conditions of all their rural road networks. Moreover, the information from the database could be used by municipal planners during the compilation of annual Integrated Development Plans (IDPs). As a result, municipal authorities will better manage the conditions of rural road networks.

\section{References}

Alzubaidi, H. (2000). Rating of Gravel Roads in Sweden. Development of a new method. TRITA-IP FR, (00-77).

Alzubaidi, H., \& Magnusson, R. (2002). Deterioration and Rating of Gravel Roads: State of the Art. Road Materials and Pavement Design, 3(3), 235-260. http://dx.doi.org/10.1080/14680629.2002.9689924

Beegle, K., Christiaensen, L., Dabalen, A., \& Gaddis, I. (2016). POVERTY RISING AFRICA. World Bank Publications.

Berkshire Regional Planning Commission. (2001). The Massachusetts Unpaved Roads BMP Manual: A Guidebook on How to Improve Water Quality While Addressing Common Problems. Project 98-06/319. http://www.mass.gov/eea/docs/dep/water/resources/a-thru-m/dirtroad.pdf.

Bhattacharya, A., Oppenheim, J., \& Stern, L. N. (2015). Driving sustainable development through better infrastructure: Key elements of a transformation program. Global Economy \& Development Working Paper, 91.

Bond, P. (1999). Basic infrastructure for socio-economic development, environmental protection and geographical desegregation: South Africa's unmet challenge. Geoforum, 30(1), 43-59. http://dx.doi.org/10.1016/S0016-7185(98)00031-1.

Briceno-Garmendia, C., \& Estache, A. (2004). Infrastructure services in developing countries: access, quality, costs, and policy reform (Vol. 3468). World Bank Publications. http://dx.doi.org/10.1596/1813-9450-3468

Chambers, R. (2014). Rural development: Putting the last first. Routledge.

Chambers, R., \& Conway, G. (1992). Sustainable rural livelihoods: practical concepts for the 21st century. Institute of Development Studies (UK). 
Chamberlin, J., \& Jayne, T. S. (2013). Unpacking the meaning of 'market access': evidence from rural Kenya. World development, 41, 245-264.

Chamorro, A., \& Tighe, S. (2009). Development of a management framework for rural roads in developing countries: integrating socioeconomic impacts. Transportation Research Record: Journal of the Transportation Research Board, (2093), 99-107. http://dx.doi.org/10.3141/2093-12.

Chamorro, A., de Solminihac, H., Salgado, M., \& Barrera, E. (2009). Development and Validation of a Method to Evaluate Unpaved Road Condition with Objective Distress Measures. Transportation Research Record: Journal of the Transportation Research Board, (2101), 3-9. http://dx.doi.org/10.3141/2101-01.

Cohen, B. (2006). Urbanization in developing countries: Current trends, future projections, and key challenges for sustainability. Technology in society, 28(1), 63-80. http://dx.doi.org/10.1016/j.techsoc.2005.10.005.

Commitee of Transport Officials. (2012). Technical Recommendations For Highways. South African Road Classification and Access Management Manual, Pretoria, South Africa.

Connerley, E., \& Schroeder, L. (1996). Rural transport planning. Approach Paper, Sub-Saharan Africa, 68, 69-71.

Faiz, A. (2012). The Promise of Rural Roads: Review of the Role of Low-Volume Roads in Rural Connectivity, Poverty Reduction, Crisis Management, and Livability. Transportation Research E-Circular, (E-C167).

Forman, R. T. (2003). Road ecology: science and solutions. Island Press.

Fu, B., Newham, L. T., \& Ramos-Scharron, C. E. (2010). A review of surface erosion and sediment delivery models for unsealed roads. Environmental Modelling \& Software, 25(1), 1-14. http://dx.doi.org/10.1016/j.envsoft.2009.07.013.

Gwilliam, K., Foster, V., Archondo-Callao, R., Brice-o-Garmendia, C., Nogales, A., \& Sethi, K. (2008). The Burden of Maintenance: Roads in Sub-Saharan Africa. Background Paper, 14.

Hanmer, L., Booth, D., \& Lovell, E. (2000). Poverty and Transport: A Report prepared for the World Bank in collaboration with DFID. Overseas Development Institute.

Hettige, H. (2006). When do rural roads benefit the poor and how?: an in-depth analysis based on case studies. Asian Development Bank, Philippines.

Hetzel, M. W., Iteba, N., Makemba, A., Mshana, C., Lengeler, C., Obrist, B., \& Mayumana, I. (2007). Understanding and improving access to prompt and effective malaria treatment and care in rural Tanzania: the ACCESS Programme. Malaria journal, 6(1), 83. http://dx.doi.org/10.1186/1475-2875-6-83.

Housing Development Agency. (2013). The Housing Development Agency annual report 2012/2013 [Online]. Johannesburg, South Africa: HDA. [Accessed 04 October 2015].

Huntington, G., \& Ksaibati, K. (2005). Gravel roads asset management. Transportation Research Circular E-C078: Roadway Preservation 2005, 214-228.

Huntington, G., \& Ksaibati, K. (2007). Gravel Roads Surface Performance Modeling. Transportation Research Record: Journal of the Transportation Research Board, (2016), 56-64. http://dx.doi.org/10.3141/2016-07

Jones, D. (2000). Draft TMH12: Pavement Management Systems: Standard Visual Assessment Manual for Unsealed Roads (Version 1). Pretoria, South Africa.

Jones, T. E. (1984). The Kenya maintenance study on unpaved roads: research on deterioration. Overseas Unit, Transport and Road Research Laboratory.

Kilkenny, M. (1998). Transport costs, the new economic geography, and rural development. Growth and Change, 29(3), 259-280. http://dx.doi.org/10.1111/0017-4815.00087

Lay, M. G. (2009). Handbook of road technology. CRC Press.

Lishman, D. (2013). A critical evaluation of road pricing in South Africa Duncan Lishman.

Lugo, A.E. and Gucinski, H., 2000. Function, effects, and management of forest roads. Forest ecology and management, 133(3), pp.249-262. http://dx.doi.org/10.1016/S0378-1127(99)00237-6.

Maser, K. R. (1996). Condition assessment of transportation infrastructure using ground-penetrating radar. Journal of infrastructure systems, 2(2), 94-101. http://dx.doi.org/10.1061/(ASCE)10760342(1996)2:2(94)

Mashiri, M., Naude, A., \& Nchabeleng, A. (2002). Rural transport strategy for South Africa. Contract Report CR2002/72. Pretoria.

Miheretu, B. A. (2011). Causes and consequences of rural-urban migration: the case of Woldiya town, North Ethiopia (Doctoral dissertation).

Mwabu, G., \& Thorbecke, E. (2004). Rural development, growth and poverty in Africa. Journal of African Economies, 13(suppl 1), i16-i65. http://dx.doi.org/10.1093/jae/ejh015.

Nkomo, S. Developing key success criteria for rural development initiatives in the context of sustainable land management, University of KwaZulu-Natal, Pietermaritzburg Campus (Masters dissertation).

Okhahlamba Local Municipality. (2015). Okhahlamba Municipality IDP Review-2015/2016, Bergville, South Africa.

Porter, G. (2014). Transport services and their impact on poverty and growth in rural Sub-Saharan Africa: a review of recent research and future research needs. Transport reviews, 34(1), 25-45. http://dx.doi.org/10.1080/01441647.2013.865148. 
Porter, G., Hampshire, K., Mashiri, M., Dube, S., \& Maponya, G. (2010). 'Youthscapes' and escapes in rural Africa: Education, mobility and livelihood trajectories for young people in Eastern Cape, South Africa. Journal of international development, 22(8), 1090-1101.

Potts, D. (2013). Rural-urban and urban-rural migration flows as indicators of economic opportunity in SubSaharan Africa: What do the data tell us. Migrating out of poverty research programme working paper.

Rivera, F., Chamorro, A., Lucero, R., \& Aravena, C. (2015). Development of Condition Indicator for Managing Sealed Rural Road Networks. Transportation Research Record: Journal of the Transportation Research Board, (2474), 90-97. http://dx.doi.org/10.3141/2474-11

Roberts, P., Kc, S., \& Rastogi, C. (2006). Rural access index: a key development indicator: The World Bank Group, Washington DC.

Sahn, D. E., \& Stifel, D. C. (2003). Urban-rural inequality in living standards in Africa. Journal of African Economies, 12(4), 564-597. http://dx.doi.org/10.1093/jae/12.4.564.

Schulze, R. E. (ed.) (2008). South African Atlas of Climatology and Agrohydrology. WRC Report No. 1489/1/08. Water Research Commission, Pretoria, RSA.

Sethi, K. (2008). The Burden of Maintenance: Roads in Sub-Saharan Africa. AICD.

Shoop, S., Affleck, R., Haehnel, R., \& Janoo, V. (2008). Mechanical behavior modeling of thaw-weakened soil. Cold Regions Science and Technology, 52(2), 191-206. http://dx.doi.org/10.1016/j.coldregions.2007.04.023.

Simonsen, E. and Isacsson, U., 1999. Thaw weakening of pavement structures in cold regions. Cold regions science and technology, 29(2), pp.135-151. http://dx.doi.org/10.1016/S0165-232X(99)00020-8

Smith, A., \& Visser, A. T. (2001). A South African Road Network Classification Based on Traffic Loading. M Eng project report, University of Pretoria.

Songco, J. A. (2002). Do Rural Infrastructure Investments Benefit the Poor?: Evaluating Linkages: a Global View, a Focus on Vietnam (Vol. 2796). World Bank Publications. http://dx.doi.org/10.1596/1813-9450-2796

Starkey, P. (Ed.). (2002). Improving rural mobility: options for developing motorized and nonmotorized transport in rural areas (Vol. 23). World Bank Publications. http://dx.doi.org/10.1596/0-8213-5185-0

Statistics South Africas. (2014). Annual report 2013/14 [Online]. Pretoria, South Africa. [Accessed 14 October 2015].

Tacoli, C. (2003). The links between urban and rural development. Environment and Urbanization, 15(1), 3-12. http://dx.doi.org/10.1177/095624780301500111

Ubuhlebezwe Local Municipality. (2015). Ubuhlebezwe Municipality IDP Review - 2015/2016, Ixopo, South Africa.

Van de Walle, D. (2002). Choosing rural road investments to help reduce poverty. World Development, 30(4), 575-589. http://dx.doi.org/10.1016/S0305-750X(01)00127-9

van der Gryp, A., \& van Zyl, G. (2007). Variability and control of gravel road visual assessments. Transportation Research Record: Journal of the Transportation Research Board, (1989), 247-253. http://dx.doi.org/10.3141/1989-70.

Wenzel, P. (2007). Public-sector transformation in South Africa Getting the basics right. Progress in Development Studies, 7(1), 47-64. http://dx.doi.org/10.1177/146499340600700105.

Yifred, K. (2013). Performance Assessment of Road Drainage Structures and Proposed Mitigation Measures: The case of Daleti-Odagodere Gravel Road in Benishangul-Gumuz Region (Doctoral dissertation, AAU).

Zhang, C., \& Elaksher, A. (2012). An Unmanned Aerial Vehicle-Based Imaging System for 3D Measurement of Unpaved Road Surface Distresses1. Computer-Aided Civil and Infrastructure Engineering, 27(2), 118-129. http://dx.doi.org/10.1111/j.1467-8667.2011.00727.x. 